\title{
Storage reservoirs beyond a lake district as secondary habitats for caddisflies (Insecta: Trichoptera) in an area of karst origin (SE Poland)
}

\author{
Edyta Buczyńska* \\ Department of Zoology, Animal Ecology and Wildlife Management, University of Life Sciences, Akademicka 13, 20-033 Lublin, Poland
}

\begin{abstract}
Shallow and vegetation-rich storage reservoirs can be a very important element of a hydrological network supporting specific fauna. However, their ecological potential for many insect groups is often neglected in hydrobiological studies in contrast to lakes. Therefore, caddisfly fauna was studied at different levels of its organization as well as environmental drivers of the species' distribution across three reservoirs (SE Poland). The species' composition and assemblages distinguishingly showed close relationships with the caddisfly fauna of meso- and eutrophic lakes. Quantitative naturalness index (Wns) of caddisfly fauna in all reservoirs was higher in comparison to this value obtained for regional lakes. Oxygen reduction potential, temperature, electrical conductivity (physical and chemical variables of water), shading, elodeids (structural variables of reservoirs) and the average distance to the nearest water bodies (landscape variables in buffer zones of reservoirs) were all significant for caddisflies in CCA models. Analysis of functional groups revealed two characteristic features of these habitats: the lack of rheophiles and an evenly balanced trophic structure. Shallow reservoirs, despite their origin and human intervention, can provide important secondary habitats for specific invertebrate fauna. Practical guidelines are also given concerning management practices favourable to aquatic biota.
\end{abstract}

Keywords: Trichoptera / functional group / storage reservoir / environmental variable / secondary habitat

Résumé - Réservoirs de stockage dans une région lacustre d'origine karstique comme habitats secondaires pour les trichoptères (Insecta: Trichoptera) (sud-est de la Pologne). Les réservoirs de stockage peu profonds et riches en végétation peuvent être un élément très important d'un réseau hydrologique soutenant une faune spécifique. Cependant, leur potentiel écologique pour de nombreux groupes d'insectes est souvent négligé dans les études hydrobiologiques, contrairement aux lacs. Par conséquent, la faune de trichoptères a été étudiée à différents niveaux de son organisation ainsi que les facteurs environnementaux de la répartition de l'espèce dans trois réservoirs (sud-est de la Pologne). La composition et les assemblages de l'espèce montraient nettement des relations étroites avec la faune de phryganes des lacs méso- et eutrophiques. L'indice quantitatif de naturalité (Wns) de la faune de trichoptère dans tous les réservoirs était plus élevé par rapport à cette valeur obtenue pour les lacs régionaux. Le potentiel d'oxydoréduction, la température, la conductivité électrique (variables physiques et chimiques de l'eau), l'ombrage, les élodéides (variables structurelles des réservoirs) et la distance moyenne aux plans d'eau les plus proches (variables du paysage dans les zones tampons des réservoirs) étaient tous importants dans les modèles CCA. L'analyse des groupes fonctionnels a révélé deux caractéristiques de ces habitats : l'absence de rhéophiles et une structure trophique équilibrée. Les réservoirs peu profonds, malgré leur origine et l'intervention humaine, peuvent fournir des habitats secondaires importants pour la faune invertébrée. Des lignes directrices pratiques sont également données concernant les pratiques de gestion favorables à ce biote aquatique.

Mots-clés: Trichoptère / groupe fonctionnel / réservoir de stockage / variable environnementale / habitat secondaire

\footnotetext{
*Corresponding author: edyta.buczynska@gmail.com
} 


\section{Introduction}

Anthropogenic aquatic habitats, including standing and flowing waters, frequently came into existence in central Europe in medieval times as a result of common carp (Cyprinus carpio L.) breeding and the construction of water mills (Buczyński, 2015). Due to the well-documented loss of biodiversity in natural waters, which had been primary habitats (Strayer and Dudgeon, 2010), anthropogenic waters may be increasingly important secondary habitats for many plant and animal species. These waters include reservoirs, i.e. man-made water bodies built for many different purposes, which determine their location, size, hydromorphology, management, etc. Although resembling lakes to a large extent, they do possess a few distinctive features that provide specific conditions affecting their biota. Reservoirs can be divided into two categories: (i) water bodies formed by damming a river (impoundments) and (ii) water bodies not constructed within a river's course but formed by waterproof banks - socalled off-river or bounded reservoirs (Chapman, 1996).

In south-eastern Poland, reservoirs are constructed by raising embankments to form dammed lakes, or by constructing dykes to elevate water levels in watershed regions of catchment areas. The latter - the subject of this paper - are relatively shallow $(<3 \mathrm{~m})$, often with a mosaic of abundant aquatic vegetation (submerged and emergent), which causes them to resemble ponds. Variations in their water level are not as dramatic as in the case of deep, dammed reservoirs (Votruba and Broža, 1989), but they are constantly subjected to various forms of human pressure, depending on their intended use. Located far from lakes, they are often the only larger water bodies where conditions are appropriate for the development of many plant and animal species with specific habitat requirements. However, in contrast to natural aquatic ecosystems, the invertebrate fauna of man-made water bodies has often been neglected, so that relevant knowledge, especially on species, assemblages or functional groups is still rudimentary (e.g. Céréghino et al., 2008; Ruhí et al., 2009; Miguel-Chinchilla et al., 2014; Buczyńska et al., 2016). This especially refers to caddisflies (Trichoptera), an important component of the freshwater macrofauna, an ideal group for ecological studies because of the great abundance of species and their broad spectrum of habitat and trophic preferences (de Moor and Ivanov, 2008; Malm et al., 2013; Čiliak et al., 2014). Moreover, being amphibiotic insects, caddisflies depend not only on strictly aquatic environmental factors but also on terrestrial ones, e.g. the type of shore or catchment area (Galbraith et al., 2008; Savić et al., 2013). Still, very little is known about these complex relationships in shallow artificial water bodies. Most papers relating to the invertebrate fauna of this kind of environment have focused on the effect of factors acting exclusively in the water and usually describe these relationships on the basis of particular higher order taxa (order or class) or selectively identified invertebrate species, without taking account of their life histories (Samways et al., 1996; Prus et al., 1999; Poznańska et al., 2009; Hu et al., 2016; Fadilah et al., 2017). However, the location of a reservoir (woodland area, peatbog, farmland), its age as well as the manner and intensity of its management also exert a certain influence on the quantitative and qualitative structure of the macroinvertebrates (Miguel-Chinchilla et al., 2014;
Buczyńska et al., 2016; Fadilah et al., 2017). Therefore, this study is focused on revealing all the possible key environmental factors, encompassing different spatial scales (from water to the buffer zones of the reservoirs) for different levels of the organization of trichopterans - species, assemblages, functional groups and ecological metrics. Such a complex approach can be useful in understanding ecological processes in artificial shallow waters and their close surroundings. Storage reservoirs are the habitats created and managed by man, therefore, in comparison with natural waters, they are $a$ priori regarded as being of lower natural value. In this study, I also wanted to determine whether different hydromorphological conditions in reservoirs resulting from their origin and management cause them to be less attractive to caddisflies than lakes.

The application of practical ecological knowledge to conservation biology has been one of the main challenges of freshwater biology (Strayer and Dudgeon, 2010). Even in reservoirs under constant human interference, it is worth trying to reconcile the interests of people and nature, because such artificial water bodies can be important for maintaining regional biodiversity, rare and valuable species/assemblages or they can act as wildlife corridors (especially in areas poor in surface waters) (Buczyński, 2015). This study also presents some guidelines for sustainable management practices in shallow storage reservoirs, regarding, for example, modifications of habitat features fostering aquatic insects and thereby other aquatic organisms.

Taking the above into consideration, the specific objectives of the present study were to (i) compare Trichoptera at different levels of their organisation (species, assemblages, diversity metrics, functional groups) in three different storage reservoirs; (ii) determine the importance of different spatialscale variables influencing caddisfly distribution in such reservoirs; (iii) assess whether and how caddisfly fauna in storage reservoirs situated beyond lake districts differs from this identified in four well-researched lakes lying in the same region.

\section{Material and methods}

\subsection{Study area and sites}

This study was carried out in three shallow storage reservoirs (R1, R2, R3) selected for their location and different characters of their hydromorphologies and landscape features (Fig. 1). Due to their position beyond the central belt of lakes forming the Łęczna-Włodawa Lake District, they are suitable study objects with the direct influence of caddisfly fauna from the nearest lakes reduced to a minimum (average distance do the centre of the lake district: $31.6 \mathrm{~km}$ - QGIS Development Team, 2015). All the reservoirs are situated in two macroregions in SE Poland: Western Polesie and Wołyń Polesie (Kondracki, 2014). The Polish part of Western Polesie is the area of denudation and accumulation plains, with 68 lakes (total area $27 \mathrm{~km}^{2}$ ) of unique thermokarst origin in the south (Michalczyk and Wilgat, 1998). Reservoirs R1 and R2 are situated in the northern part of this region: R1 in a fen-marshy plain supporting meadows and woodland, R2 within flattopped elevations of moraine clay and sandy depressions. Reservoir R3 is located in Wołyń Polesie, the area with upland 


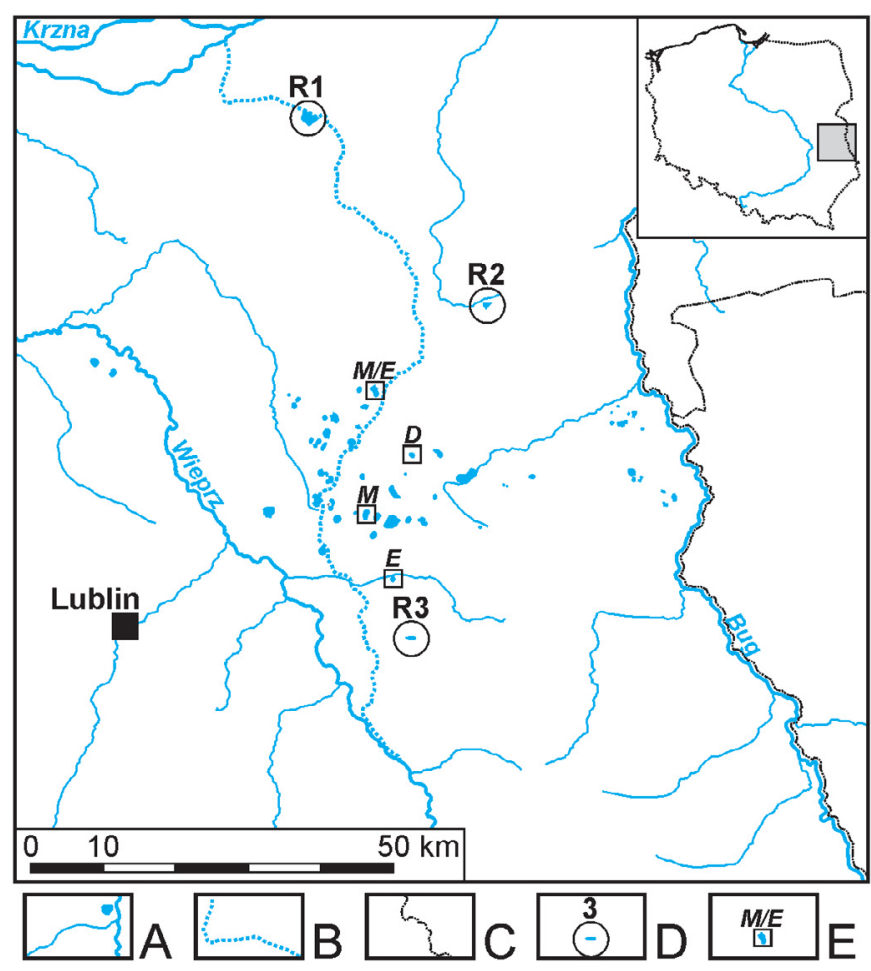

Fig. 1. Study area. A - hydrological network (rivers and lakes), B - the Wieprz-Krzna Canal, C - national border, D - storage reservoir (R1, R2, R3), E - lake (D - the dystrophic Lake Moszne, $\mathrm{M}$ - the mesotrophic Lake Piaseczno, M/E - the meso-eutrophic Lake Skomielno, E - the eutrophic Lake Głębokie) for comparison.

influences, formed by a layer of lime-chalk marl covered by Pleistocene sands, rich in peat bogs and sand dunes (Kondracki, 2014). It consists mainly of meadows, and to a lesser extent of arable land. All three reservoirs were created in the same way: by constructing waterproof banks to dam the water. Fish - mainly Cyprinus carassius L., Carassius gibelio (Bloch), Tinca tinca (L.), Abramis brama (L.), Perca fluviatilis L., and Rutilus rutilus (L.) - are farmed in all three reservoirs so the impact of fish on aquatic invertebrates is comparable. General characteristics of the reservoirs with regard to their origin, age, size, basins, surroundings (catchment areas) and management are given in Table 1.

\subsection{Sampling procedures}

Caddisflies were sampled in spring (April, May), summer (June, August) and autumn (October, November) 2011. In every reservoir, six sampling areas of $1 \mathrm{~m}^{2}$ were delineated along the shoreline: three in the shallow littoral (maximum water depth $0.5 \mathrm{~m}$ ) and three in the deeper littoral (maximum water depth $1.5 \mathrm{~m}$ ) so as to include all possible microhabitat features (substratum, extent of development of aquatic plants, shading). The caddisflies were collected with a hydrobiological kick-sampler (mesh size $250 \mu \mathrm{m}$ ). The material was sorted in the laboratory and preserved in $70 \%$ ethyl alcohol. Next, all specimens were identified to species level with the use of Edington and Hildrew (1995) and Wallace et al. (2003). The exceptions were larvae of the Anabolia genus Stephens, 1837, which belong to two species (A. furcata Brauer, 1857 or A. laevis Zetterstedt, 1840) inseparable at this stage, as well as some early instar individuals that were identified to genus level.

\subsection{Environmental parameters}

To analyse the relationships between caddisflies and their environment, three groups of different variables were selected: (i) the physical and chemical properties of water, (ii) the structural features of the reservoirs and (iii) landscape parameters. Physical and chemical parameters: water temperature $\left({ }^{\circ} \mathrm{C}\right), \mathrm{pH}$, oxygen reduction potential (ORP) $(\mathrm{mV})$, dissolved oxygen concentration (DO) (ppm), electrical conductivity (EC) $(\mu \mathrm{S} / \mathrm{cm})$, total dissolved solids (TDS) (ppm) and salinity (Salin) (PSU) - were measured in situ using a Hanna HI 9828 multiparameter portable meter. The structural parameters covered substrate composition, which was assessed within $1 \mathrm{~m}^{2}$ of the sampling area and allocated to one of four categories on the basis of grain size: mud (coded as 0), mudsand (1), sand (2), and concrete blocks (3). Water depth was measured in situ during sampling. Five classes describing the extent of development of helophytes and elodeids were distinguished and coded for further analysis as follows: 0-no plants, 1-plants poorly developed, 2-moderately developed, 3-well developed, 4-very well developed. An analogous method was used for the shading factor - identical classes were distinguished for trees and shrubs on the shore. Moreover, the degree of shoreline indentation (K) of each reservoir was calculated according to the formula used in limnology for lakes: $K=L / P$, where $L$ is the length of the shoreline and $P$ is the area of the water body.

The third group of environmental variables involved the analysis of landscape measurements in the buffer zones around each sampling site and was calculated with the use of Quantum Gis 1.8.0. software (QGIS Development Team, 2015). Vectorisation of these areas within $500 \mathrm{~m}$ of every sampling site was based on 1:10,000 orthophotomaps and field data. Seven different landscape classes were distinguished: buildings, roads, wet meadows and fens, arable land, water, tall emergent vegetation and forests. The main measurement of the landscape structure was the total area $\left(\mathrm{m}^{2}\right)$ of particular classes. The distances $(\mathrm{m})$ to the nearest body of standing water (small pools or fens) and to the nearest running water (a small river or canal) were measured for every site.

Environmental variables of the reservoirs used in further statistical multivariate analysis are provided in Table 1.

\subsection{Data analysis}

Caddisflies were analysed at different levels - species, assemblages, diversity metrics and functional groups (FG) with regard to their feeding behaviour and current preferences.

Data collected from four lakes from the same region with different levels of productivity - the dystrophic Lake Moszne (D), the mesotrophic Lake Piaseczno (M), the meso-eutrophic Lake Skomielno (M/E) and the eutrophic Lake Głębokie (E) were used to compare the fauna of the lakes with that of the reservoirs (Fig. 1). The data from these lakes are taken from the literature (Czachorowski and Kornijów, 1993; 
E. Buczyńska: Knowl. Manag. Aquat. Ecosyst. 2019, 420, 4

Table 1. General features and the mean values (with SD) of environmental variables of the reservoirs R1, R2 and R3. Codes of environmental variables used in CCAs and units are given in brackets.

\begin{tabular}{|c|c|c|c|}
\hline Feature & $\mathrm{R} 1$ & $\mathrm{R} 2$ & R3 \\
\hline \multicolumn{4}{|l|}{ General features of the reservoirs } \\
\hline Creation date & 1971 & 1968 & 2000 \\
\hline Altitude ( $\mathrm{m}$ asl) & 149.4 & 158.6 & 171.0 \\
\hline Area (ha) & 350 & 240 & 48 \\
\hline Depth (m) & $\max .2 .5$, mean 1.97 & $\max .3 .0$, mean 1.5 & $\max .2 .5$, mean 2.3 \\
\hline Degree of shoreline indentation $(\mathrm{K})$ & 0.02 & 0.03 & 0.08 \\
\hline Capacity $\left(\mathrm{mln} \mathrm{m}^{3}\right)$ & 6.9 & 5.0 & 1.13 \\
\hline Water supply & Wieprz-Krzna Canal & Wieprz-Krzna Canal & River Mogielnica \\
\hline Original area & fen meadows & fen meadows & $\begin{array}{l}\text { fens in a river valley } \\
\text { with peat excavations }\end{array}$ \\
\hline Dominating surrounding type & $\begin{array}{l}\text { Wet meadows secondary } \\
\text { turned into } \\
\text { swamps, forests }\end{array}$ & $\begin{array}{l}\text { Alder and mixed forests, } \\
\text { croplands, pastures }\end{array}$ & $\begin{array}{l}\text { Croplands and dried } \\
\text { out meadows, mixed } \\
\text { forests and fens }\end{array}$ \\
\hline Purpose & $\begin{array}{l}\text { Agricultural usage, } \\
\text { fisheries management }\end{array}$ & $\begin{array}{l}\text { Agricultural usage, fisheries } \\
\text { management }\end{array}$ & $\begin{array}{l}\text { Fisheries management, } \\
\text { recreation }\end{array}$ \\
\hline \multicolumn{4}{|l|}{ Environmental variables } \\
\hline \multicolumn{4}{|l|}{ Physical and chemical parameters of water } \\
\hline Temperature $\left(\right.$ Temp, $\left.{ }^{\circ} \mathrm{C}\right)$ & $15.0 \pm 9.0$ & $20.8 \pm 9.9$ & $14.62 \pm 8.5$ \\
\hline $\mathrm{pH}$ & $8.4 \pm 0.33$ & $8.0 \pm 0.38$ & $8.3 \pm 0.38$ \\
\hline Oxygen reduction potential (ORP, mV) & $-35.69 \pm 27.9$ & $73.21 \pm 42$ & $75.45 \pm 44.22$ \\
\hline $\begin{array}{l}\text { Dissolved oxygen } \\
(\mathrm{DO}, \mathrm{ppm})\end{array}$ & $7.31 \pm 1.4$ & $7.41 \pm 1.8$ & $7.66 \pm 0.6$ \\
\hline $\begin{array}{l}\text { Electrical conductivity } \\
(\mathrm{EC}, \mu \mathrm{S} / \mathrm{cm})\end{array}$ & $367 \pm 29$ & $215 \pm 59$ & $298 \pm 81$ \\
\hline $\begin{array}{l}\text { Total dissolved solids } \\
\text { (TDS, } \mathrm{ppm} \text { ) }\end{array}$ & $191.28 \pm 5.6$ & $105.93 \pm 3.8$ & $181.44 \pm 9.7$ \\
\hline Salinity (Salin, PSU) & $0.18 \pm 0.005$ & $0.1 \pm 0.004$ & $0.16 \pm 0.006$ \\
\hline \multicolumn{4}{|l|}{ Structural parameters of reservoirs } \\
\hline Water depth (Depth, m) & $0.8 \pm 0.4$ & $0.9 \pm 0.67$ & $0.73 \pm 0.23$ \\
\hline Bottom type (Bottom) & $1.37 \pm 0.48$ & $1.27 \pm 0.45$ & $1.8 \pm 0.95$ \\
\hline Elodeids (Elodeids) & $2.54 \pm 0.5$ & $3.57 \pm 0.83$ & $1.15 \pm 1.75$ \\
\hline Helophytes (Heloph) & $2.20 \pm 0.4$ & $2.51 \pm 0.5$ & $1.88 \pm 1.52$ \\
\hline Shade (Shade) & 0 & $1 \pm 0.5$ & $0.8 \pm 0.33$ \\
\hline \multicolumn{4}{|c|}{ Landscape parameters in buffering zones of reservoirs (areas or distances) } \\
\hline Forests (Forests, $\mathrm{m}^{2}$ ) & $579 \pm 27$ & $4547 \pm 532$ & $1581 \pm 52$ \\
\hline Wet meadows and fens (Meadows, $\mathrm{m}^{2}$ ) & $26609 \pm 2363$ & $3905 \pm 632$ & $7677 \pm 571$ \\
\hline Water $\left(\right.$ Water, $\mathrm{m}^{2}$ ) & $19829 \pm 5122$ & $13928 \pm 1822$ & $5590 \pm 799$ \\
\hline Tall emergent vegetation $\left(\mathrm{TEV}, \mathrm{m}^{2}\right)$ & $8356 \pm 1876$ & $872 \pm 40$ & $309 \pm 9$ \\
\hline Distance to the nearest standing water body (SW_dista, $m$ ) & $3240 \pm 40$ & $1270 \pm 50$ & $52 \pm 10$ \\
\hline Distance to the nearest running water (RW_dista, $\mathrm{m}$ ) & $20 \pm 10$ & $994 \pm 30$ & $130 \pm 22$ \\
\hline
\end{tabular}

Czachorowski and Buczyński, 1999b; Buczyńska, 2012a, $2012 \mathrm{~b}$ ) and the author's database.

The following ecological indices were used: $D-$ dominance (Biesiadka, 1980), C - constancy of occurrence (Szujecki, 1983), E - evenness (Buzas and Gibson, 1969) and PIE (Probability of an Interspecific Encounter) diversity index according to Hurlbert's formula (Lampert and Sommer, 1999). Naturalness indices (Wns - quantitative formula, Wni qualitative formula) on the basis of Fischer's formula (1996), modified by Czachorowski and Buczyński (1999a), were applied to rate and the faunas of the reservoirs and the four lakes were compared. The values of Wns and Wni indicate whether the fauna is specialised and typical of the habitat (lake) or is composed of non-specialists (eurytopes). To calculate Wns and Wni, the stenotopy index (Wze) is needed, which is attributed to every species from a particular type of habitat. The Wze value - indicating the extent to which species are associated with lake habitats - ranges from 0 (for eurytopes) to 16 (for specialized lacustrine species). All Wze values for the species are taken from literature (Czachorowski, 2004) or defined individually by the author.

Two-way indicator species analysis TWINSPAN was used to construct the dendrogram with caddisfly assemblages in the reservoirs and to distinguish first-division indicators for this type of anthropogenic habitat. Species with less than two occurrences were excluded from this analysis. TWINSPAN 
Table 2. Caddisflies (Trichoptera) recorded in the reservoirs R1, R2 and R3. FG - functional group based on feeding and current preferences, Wze - stenotopy index of the species, Den - density (per sample), D - dominance, C - constancy of occurrence. Eudominant species given in bold.

\begin{tabular}{|c|c|c|c|c|c|c|c|c|c|c|c|c|c|c|}
\hline \multirow[t]{2}{*}{ No. } & \multirow[t]{2}{*}{ Species } & \multirow[t]{2}{*}{ Code } & \multicolumn{2}{|c|}{ FG } & \multirow[t]{2}{*}{ Wze } & \multicolumn{3}{|c|}{ Reservoir 1} & \multicolumn{3}{|c|}{ Reservoir 2} & \multicolumn{3}{|c|}{ Reservoir 3} \\
\hline & & & Feeding & Current & & Den & $\mathrm{D}$ & $\mathrm{C}$ & Den & $\mathrm{D}$ & $\mathrm{C}$ & Den & $\mathrm{D}$ & $\mathrm{C}$ \\
\hline 1. & Agraylea sexmaculata Curt. & Agr_sex & alg-pie & lib & 16 & 4 & 1.57 & 8 & - & - & - & - & - & $\overline{-}$ \\
\hline 2. & Agrypnia obsoleta (Hag.) & Agr_obs & pre-shr & lip & 8 & 6 & 2.36 & 8 & - & - & - & - & - & - \\
\hline 3. & Agrypnia pagetana Curt. & Agr_pag & pre-shr & lib & 8 & 4.86 & 13.39 & 58 & - & - & - & 5 & 4.29 & 15 \\
\hline 4. & Agrypnia picta Kol. & Agr_pic & pre-shr & lip & 16 & 1 & 0.39 & 8 & - & - & - & - & - & - \\
\hline 5. & Agrypnia varia (Fabr.) & Agr_var & pre-shr & lib & 8 & 6 & 4.72 & 17 & 1 & 0.56 & 8 & - & - & - \\
\hline- . & Agrypnia sp. & - & - & - & - & 2 & 1.57 & 17 & - & - & - & - & - & - \\
\hline- . & Anabolia sp. & Ana_sp & shr-pre & lip & 8 & - & - & - & - & - & - & 1.33 & 0.86 & 12 \\
\hline 6. & Athripsodes aterrimus (Steph.) & Ath_ate & $\operatorname{shr}$ & $\operatorname{lrp}$ & 16 & - & - & - & 10.33 & 17.22 & 25 & 2.67 & 3.43 & 23 \\
\hline- . & Ceraclea $\mathrm{sp}$. & Cer_sp & - & - & - & - & - & - & 3 & 1.67 & 8 & - & - & - \\
\hline 7. & Cyrnus crenaticornis (Kol.) & Cyr_cre & pre & lib & 16 & 7.40 & 14.57 & 42 & 11.33 & 18.89 & 25 & 16 & 10.3 & 12 \\
\hline 8. & Cyrnus flavidus McL. & Cyr_fla & pre & lib & 16 & - & - & - & 4.67 & 7.78 & 25 & 18.83 & 24.25 & 23 \\
\hline 9. & Cyrnus insolutus McL. & Cyr_ins & pre & lip & 16 & - & - & - & 2 & 1.11 & 8 & 1 & 0.43 & 8 \\
\hline- . & Cyrnus sp. & - & - & - & - & - & - & - & 3 & 1.67 & 8 & 1 & 0.21 & 4 \\
\hline 10. & Ecnomus tenellus (Ramb.) & Ecn_ten & pre & lip & 8 & - & - & - & - & - & - & 6.13 & 10.52 & 38 \\
\hline 11. & Holocentropus dubius (Ramb.) & Hol_dub & pre & lib & 16 & 1 & 0.39 & 8 & - & - & - & - & - & - \\
\hline 12. & Leptocerus tineiformis Curt. & Lep_tin & $\mathrm{shr}$ & lib & 16 & 2.50 & 3.94 & 33 & 4.25 & 9.44 & 33 & - & - & - \\
\hline 13. & Limnephilus decipiens (Kol.) & Lim_dec & shr-pre & lib & 16 & - & - & - & 1 & 0.56 & 8 & - & - & - \\
\hline 14. & Limnephilus flavicornis (Fabr.) & Lim_fla & shr-pre & lip & 8 & 8 & 6.3 & 17 & - & - & - & 2 & 0.43 & 4 \\
\hline 15. & Limnephilus nigriceps (Zett.) & Lim_nig & shr-pre & lip & 16 & 6 & 2.36 & 8 & 1 & 0.56 & 8 & - & - & - \\
\hline 16. & Limnephilus politus McL. & Lim_pol & shr-pre & lip & 16 & 3.50 & 2.76 & 17 & - & - & - & 1 & 0.21 & 4 \\
\hline 17. & Limnephilus stigma Curt. & Lim_sti & shr-pre & lib & 1 & 10 & 3.94 & 8 & - & - & - & 2 & 0.43 & 4 \\
\hline- . & Limnephilus sp. & - & - & - & - & - & 15.75 & 58 & 3 & 5 & 25 & 4 & 1.72 & 8 \\
\hline 18. & Molanna angustata Curt. & Mol_ang & pre & lip & 16 & 6 & 2.36 & 8 & - & - & - & 1 & 0.43 & 8 \\
\hline 19. & Mystacides longicornis (L.) & Mys_lon & gat & lip & 16 & 2 & 1.57 & 17 & 14.33 & 23.89 & 33 & 12.4 & 13.3 & 19 \\
\hline 20. & Mystacides nigra (L.) & Mys_nig & gat & lip & 16 & - & - & - & - & - & - & 3.27 & 7.73 & 42 \\
\hline 21. & Oecetis furva (Ramb.) & Oec_fur & shr-pre & lib & 16 & 1.67 & 1.97 & 25 & 1 & 1.67 & 25 & 10.05 & 9.01 & 15 \\
\hline 22. & Oecetis ochracea (Curt.) & Oec_och & pre & lib & 16 & 1 & 0.39 & 8 & - & - & - & 2.33 & 1.5 & 12 \\
\hline 23. & Orthotrichia costalis (Curt.) & Ort_cos & alg-pie & lib & 16 & - & - & - & 6 & 3.33 & - & 5.33 & 3.43 & 12 \\
\hline 24. & Phryganea bipunctata Retz. & Phr_bip & pre-shr & lib & 16 & 1 & 0.39 & 8 & - & - & - & 6.67 & 4.29 & 12 \\
\hline 25. & Phryganea grandis L. & Phr_gra & pre-shr & lib & 16 & 2.60 & 5.12 & 42 & - & - & 8 & 2.25 & 1.93 & 15 \\
\hline \multirow[t]{4}{*}{26.} & Triaenodes bicolor (Curt.) & Tri_bic & $\operatorname{shr}$ & lib & 16 & 12 & 14.17 & 25 & 4 & 6.67 & 25 & 2 & 1.29 & 12 \\
\hline & Number of species & - & - & - & - & 19 & - & - & 12 & - & - & 19 & - & - \\
\hline & Number of individuals & - & - & - & - & 254 & - & - & 180 & - & - & 466 & - & - \\
\hline & Mean density & - & - & - & - & 4.48 & - & - & 4.66 & - & - & 5.3 & - & - \\
\hline
\end{tabular}

calculations were performed in WinTWINS 2.3 (Hill and Šmilauer, 2005).

Non-metric multidimensional scaling (NMDS) with a minimum spanning tree (MST) was used to reveal the faunistic similarities between the reservoirs and the four lakes. Calculations were based on the Bray-Curtis index. The analysis was performed in the PAST 3.16 program (Hammer et al., 2001).

To define the trophic structure of the faunas of each reservoir, all taxa were assigned to one of six functional feeding groups: alg-pie - algae-piercers, gat - gatherers, shr - shredders, shr-pre - shredder-predators, pre-shr - predatorshredders, pre - predators (Czachorowski, 1998; Graf et al., 2008; the author's database). In the case of the polyphagous taxa, two dominant categories were selected (Tab. 2). The classification regarding current preferences proposed by Graf et al. (2008) was used, encompassing six categories (limnobionts, limnophils, limno-rheophils, rheo-limnophils, rheophils and rheolimnobionts). The collected species represented first three categories: limnobionts, limnophils and limno-rheophiles only (Tab. 2).

Multivariate techniques were performed in Canoco 4.5 (ter Braak and Smilauer, 2002) in order to model the particular response of caddisflies inhabiting the reservoirs to environmental variables from three different groups/levels. Three separate analyses were performed to prevent an overlap of the influence of different types of variables (physical and chemical, structural and landscape variables). The caddisfly matrix contained no data with determinations above the species level except for Anabolia sp. Data were not transformed (O'Hara and Kotze, 2010). Detrended Correspondence Analysis (DCA) was undertaken first to determine the gradient length. This value was large $(\mathrm{SD}=5.4)$; therefore, Canonical Correspondence Analysis (CCA) was used. To test 
Table 3. Ecological metrics of the storage reservoirs (R1, R2, R3) and lakes (E, M, M/E, D).

\begin{tabular}{|c|c|c|c|c|c|c|c|c|c|}
\hline \multirow[t]{2}{*}{ Metrics } & \multicolumn{4}{|c|}{ Storage reservoirs } & \multicolumn{5}{|c|}{ Lakes } \\
\hline & $\mathrm{R} 1$ & $\mathrm{R} 2$ & $\mathrm{R} 3$ & R-total & $\mathrm{E}$ & M & $\mathrm{M} / \mathrm{E}$ & $\mathrm{D}$ & L-total \\
\hline Number of taxa & 21 & 15 & 21 & 31 & 11 & 15 & 34 & 20 & 44 \\
\hline PIE & 0.63 & 0.47 & 0.67 & 0.89 & 0.36 & 0.76 & 0.77 & 0.63 & 0.80 \\
\hline Wns & 13.38 & 14.93 & 14.05 & 13.45 & 15.27 & 14.47 & 12.21 & 10.40 & 11.27 \\
\hline Wni & 12.26 & 15.47 & 14.51 & 14.07 & 15.80 & 15.17 & 15.22 & 14.00 & 14.80 \\
\hline Evenness & 0.62 & 0.58 & 0.54 & 0.55 & 0.22 & 0.46 & 0.26 & 0.31 & 0.23 \\
\hline
\end{tabular}

the significance of the environmental variables $(P<0.05)$, forward selection (FS) was used with Monte Carlo permutation tests (999 unrestricted permutations). In the analysis considering structural factors, the degree of shoreline indentation $(\mathrm{K})$ was treated as a covariable in accordance with the recommendation of Lepš and Šmilauer (2003) for this particular statistical method. Among landscape variables in buffer zones, a Spearman rank order correlation detected highly correlated parameters $(r \geq 0.8)$ : three variables - roads, buildings and arable land - were therefore removed from the analysis, the parameter matrix thereby being reduced to six factors.

\section{Results}

\subsection{Diversity metrics, assemblages and indicators of the caddisfly fauna in the storage reservoirs}

In general, 900 individuals of Trichoptera representing 26 species were caught in the reservoirs (Tab. 2). Species richness was the highest in R1 and R3 (19 species each), together with respective PIE values of 0.63 and $0.67 ; \mathrm{R} 2$ had 7 fewer species and a PIE of 0.47 (Tab. 3). The average caddisfly densities per sample were more similar: 4.5, 4.6 and 5.3 in R1, R2 and R3, respectively. Taxa richness and PIEs of the reservoirs had no patterns in common during the study (Fig. 2). Taxa richness in R1 increased gradually until summer, but decreased conspicuously in autumn. By contrast, there were two peaks of taxa richness in R2 and R3-in summer and autumn. PIE reached maximum values in different months and seasons in each reservoir (Fig. 2b).

The species distribution in the various dominance classes (Tab. 2) showed that the caddisfly fauna of the three reservoirs differed significantly. Cyrnus crenaticornis was the only eudominant species common to all the reservoirs. Representatives of the Agrypnia genus and large numbers of Triaenodes bicolor were characteristic of R1, whereas Cyrnus and Mystacides taxa were specific to R2 and R3. Large numbers of Athripsodes aterrimus were characteristic of and exclusive or nearly so to R2; the same refers to Ecnomus tenellus with respect to R3.

TWINSPAN analysis distinguished four caddisfly assemblages (Fig. 3) typical of shallow reservoirs as well as four indicator species for the first division: Cyrnus flavidus and Mystacides nigra (positive group) and C. crenaticornis and Agrypnia pagetana (negative group). The primary division clearly separated assemblage A1 from A2-A4. Two species E. tenellus and Leptocerus tineiformis - were the leaststrongly associated with these groups.
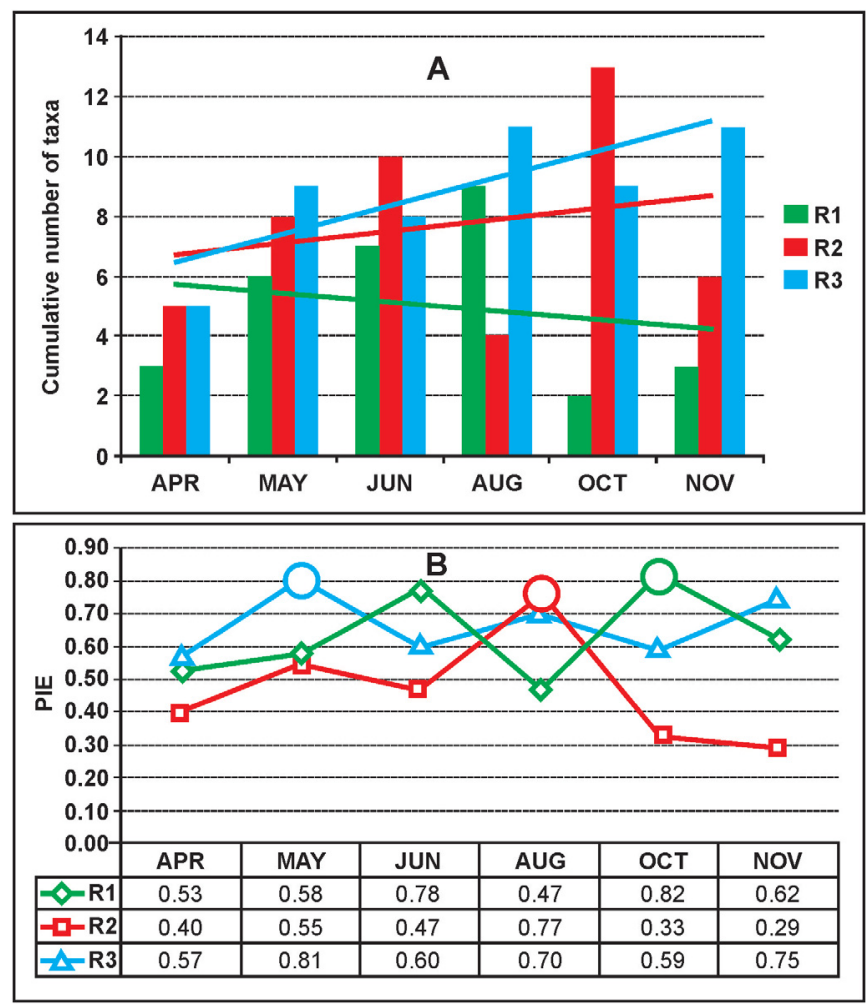

Fig. 2. Seasonal changes in faunistic metrics of the storage reservoirs R1, R2 and R3: A - taxa richness with trend line, B - PIE index (circles indicate maximum values for each reservoir).

\subsection{Reservoirs versus lakes - faunistic similarities and naturalness indices}

The comparison of the reservoir caddisflies with those of the four lakes in the region showed that in general the storage reservoirs were faunistically separate from the lakes, as they occupied opposite sides of the NMDS plot (Fig. 4). Coordinate axis 2 was correlated with the origin of the water body (artificial versus natural). In turn, coordinate axis 1 indicated the trophic gradient (from dystrophic, through eutrophic to mesotrophic). In general, the dystrophic lake fauna was the most distinctive. Among the reservoirs, R2 and R3 exhibited the greatest faunistic similarity (41\%), and their caddisfly fauna displayed a clear similarity to that of mesotrophic lakes. $\mathrm{R} 1$, situated on the opposite side of axis 2 , had a taxonomic composition similar to that of the eutrophic lake. R2 could be treated as a link between R1 and R3, and was intermediate with 


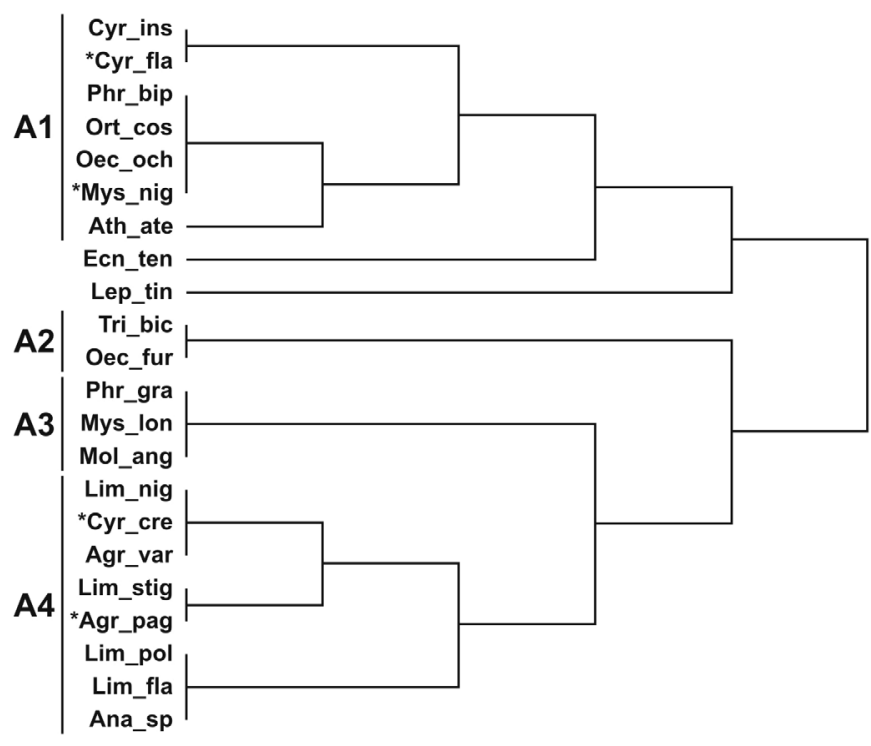

Fig. 3. TWINSPAN dendrogram showing caddisfly assemblages (A1, A2, A3, A4) inhabiting shallow storage reservoirs. First division indicator species are denoted by *.

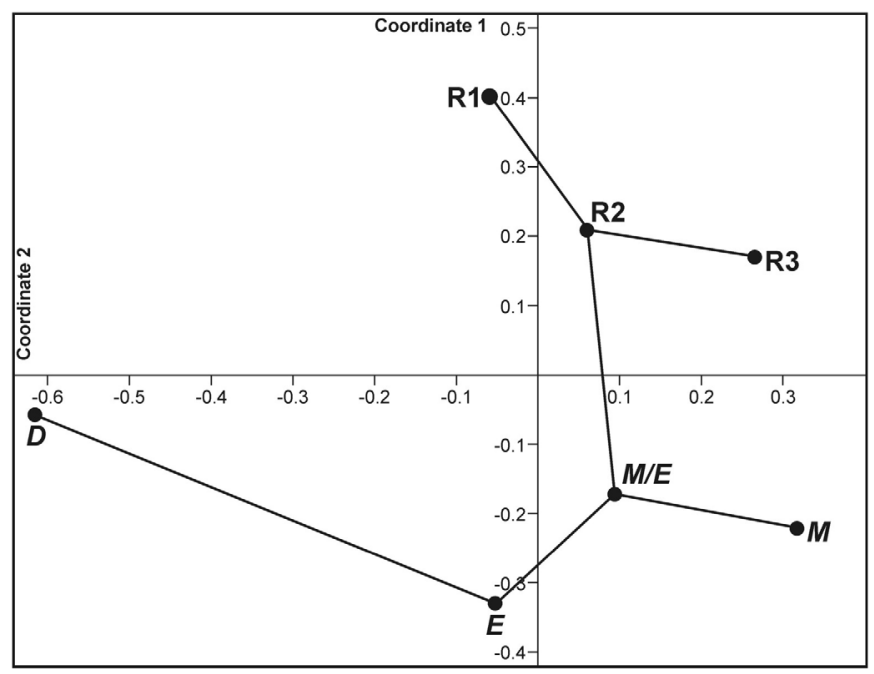

Fig. 4. Two-dimensional non-metric multidimensional scaling (NMDS) plot showing the faunistic similarities between the reservoirs (R1, R2, R3) and four lakes (D, E, M, M/E) of different productivity (based on Bray-Curtis index).

regard to species preference in the productivity of a water body.

The Wni index for the reservoirs (Tab. 3) was the highest for R2-15.47, lower for R3-14.51, and the lowest for R112.26. Respective values of Wns were lower at 14.93, 14.05 and 13.38. The values of both indices for all species recorded in the reservoirs were $\mathrm{Wni}-14.07$ and Wns -13.45 . In contrast, the comparative values for the four lakes (Tab. 3) were as follows: the most typical lacustrine fauna was found in the eutrophic lake (Wni - 15.8 and Wns - 15.27). In the mesoeutrophic and mesotrophic lakes, Wni values were much the same at 15.22 and 15.17 , whereas Wns was higher - 14.47-in the mesotrophic lake but only 12.21 in the meso-eutrophic
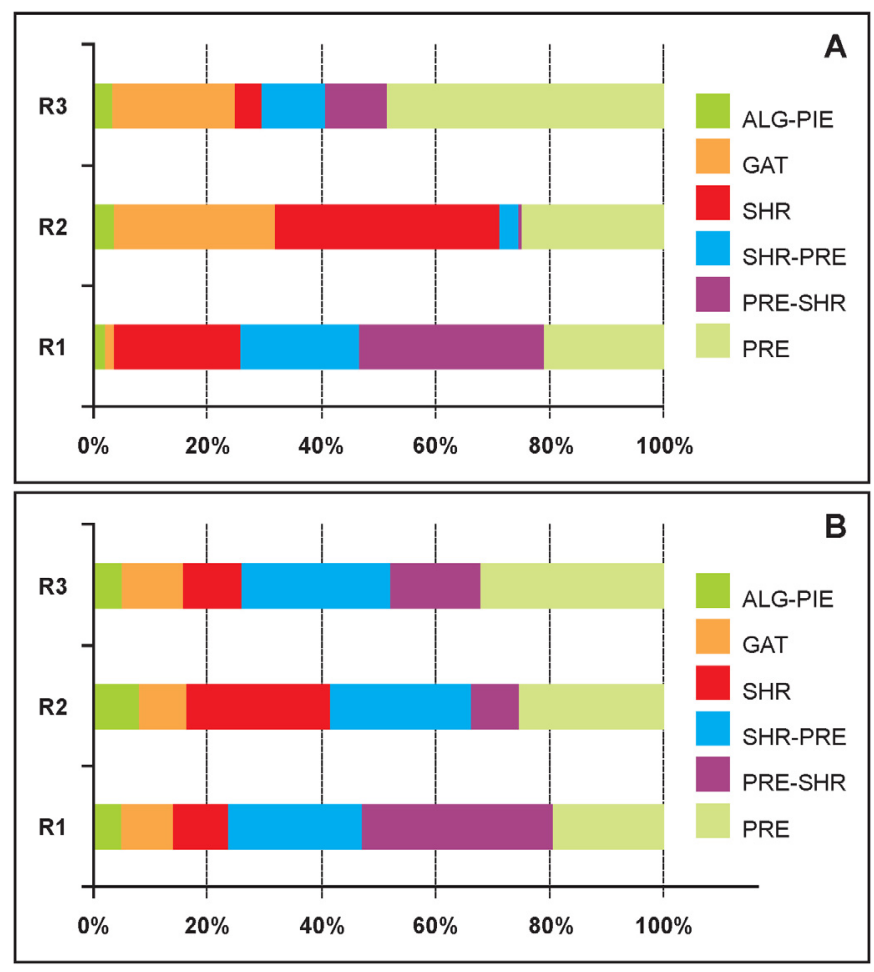

Fig. 5. Functional feeding groups of caddisfly larvae (alg-pie - algaepiercers, gat - gatherers, shr - shredders, shr-pre - shredderpredators, pre-shr - predator-shredders, pre - predators) in each reservoir (R1, R2, R3): A - percentage contribution of individuals, $\mathrm{B}-$ percentage contribution of taxa.

lake. The lowest values of both indices were recorded in the dystrophic lake: Wni -14 and Wns -10.40 . The indices calculated for the entire lacustrine fauna of this region were Wni -14.08 and Wns -11.27 .

\subsection{Functional groups of trichopterans in the storage reservoirs}

The quantitative proportions of the six functional feeding groups inhabiting the reservoirs (Fig. 5A) showed that R1 had the most evenly balanced structure, with just a slight prevalence of phryganeid predator-shredders. R2 was dominated by shredders (40\%), while the percentages of gatherers and predators were very similar (26 and $28 \%$ ). Nearly half $(48 \%)$ of all the individual caddisflies in R3 were predators, and $21 \%$ of them were gatherers. In turn, the qualitative structure of these reservoirs (Fig. 5B) showed clearly that the proportions of the various functional feeding groups were very similar in each one. With just small exceptions (predatorsshredders in R1, shredders in R2 and predators in R3), the trophic niches were occupied to an almost equal extent by larvae with different feeding behaviours.

In the case of storage reservoirs fed from watercourses, an analysis of the taxonomic structure relating to current preferences of species can yield important results (Fig. 6). The species identified in the three reservoirs could be placed in only three categories: limnobionts, limnophils and limnorheophiles, while rheo-limnophils, rheophiles or rheobionts 

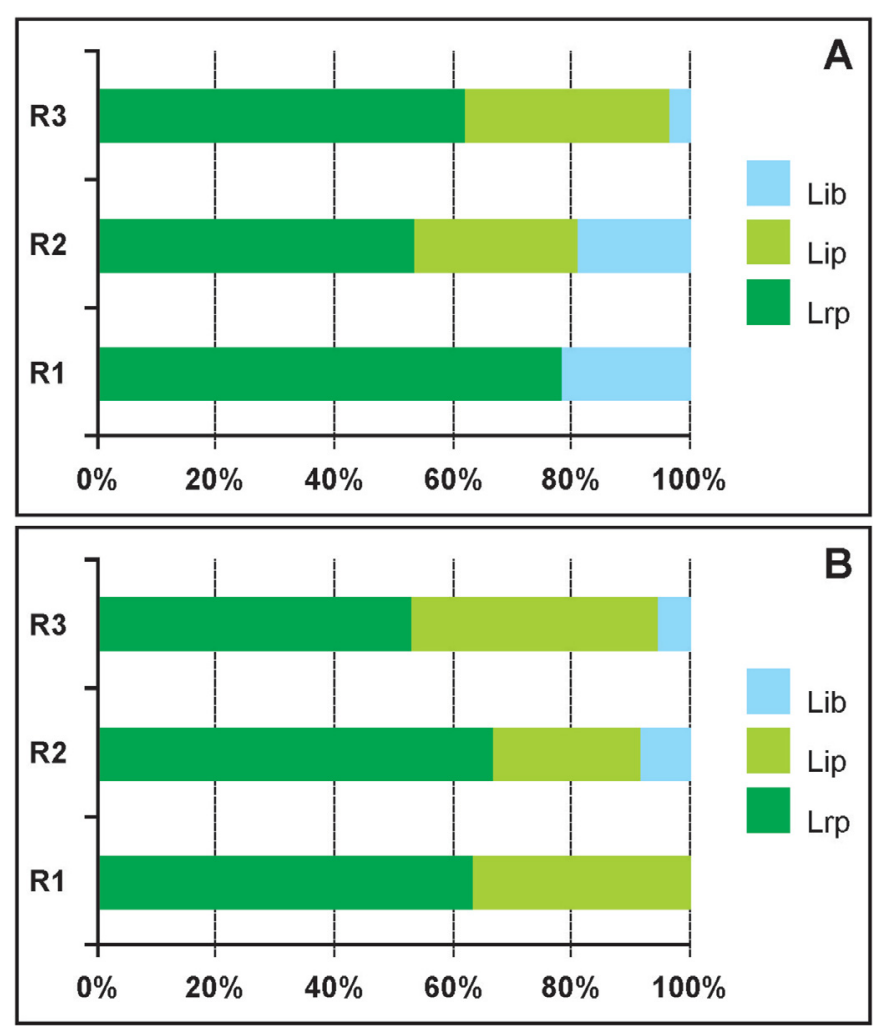

Fig. 6. Functional groups of caddisfly larvae based on current preferences (Lib - limnobionts, Lip - limnophils, Lrp - limnorheophiles) in each reservoir (R1, R2, R3): A - percentage contribution of individuals, $\mathrm{B}-$ percentage contribution of taxa.

were absent in all of them. Quantitative and qualitative analysis gave very similar results. Limno-rheophilic species were not present in R1 but were the most abundant in R2. Limnobionts always made up more than half of the individuals/ taxa found: the largest number of individuals was in R1, and the largest number of taxa in R2. Limnophils were the most numerous in R3. The largest number of individuals with the greatest affinity for flowing water was found in R2, and the largest number of species in this respect in $\mathrm{R} 3$.

\subsection{The influence of environmental variables from three spatial levels on the distribution of caddisfly species}

CCA of the physical and chemical water parameters of the reservoirs showed that three variables explained $28 \%$ of the total trichopteran species variance (Fig. 7): ORP (conditional importance $\lambda a=0.49, F=2.52, p=0.002$ ), EC (conditional importance $\lambda a=0.43, F=2.1, p=0.002$ ) and temperature (conditional importance $\lambda a=0.34, F=1.83, p=0.032$ ). Along the gradient of the first axis, the highest positive correlation between the variables used and species distribution was for ORP $(r=0.61)$, and along the second axis for EC $(r=0.70)$. A. aterrimus, E. tenellus and Orthotrichia costalis were the species most strongly positively correlated with low ORP values. A large group of species - mainly representatives of the Agrypnia and Limnephilus genera - occupied the part of

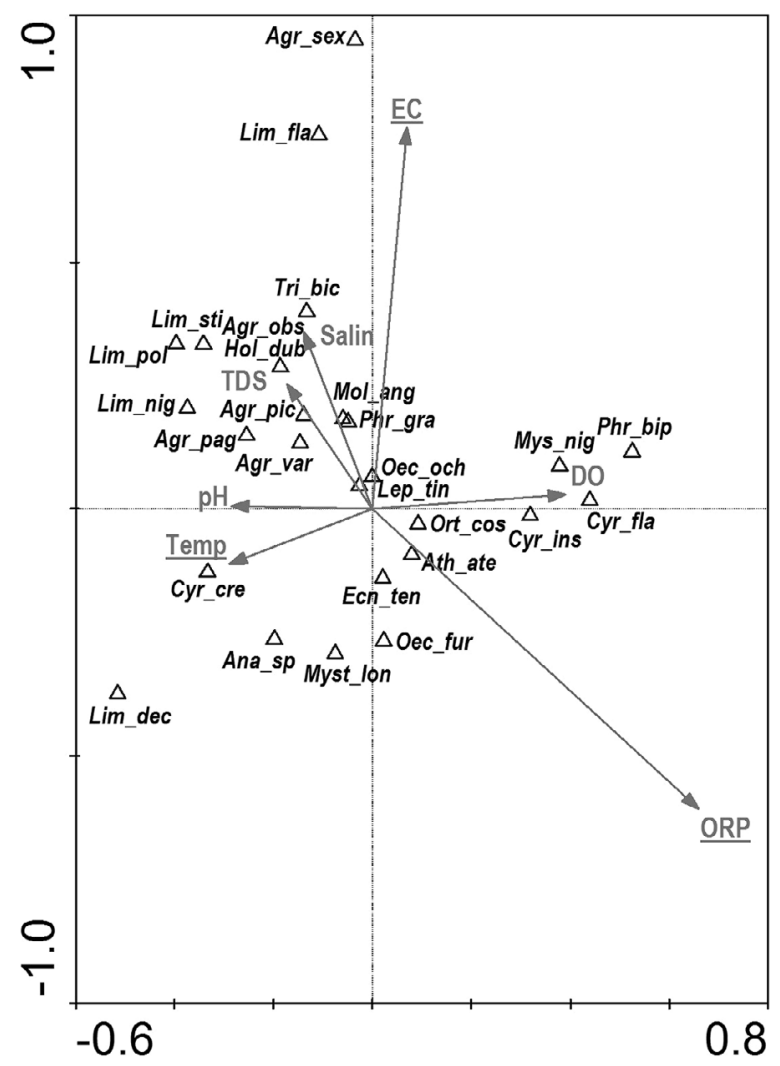

Fig. 7. CCA biplot showing the distribution of trichopteran taxa in storage reservoirs versus the physical and chemical properties of water (Temp - water temperature, $\mathrm{pH}, \mathrm{ORP}$ - oxygen reduction potential, DO - dissolved oxygen concentration, EC - electrical conductivity, total TDS - dissolved solids, Salin - salinity). Statistically significant parameters are underlined. The taxon codes are explained in Table 2 .

the biplot opposite the ORP arrow: at the same time, they were evidently positively correlated with TDS. Highest temperatures were the most important for $C$. crenaticornis and, to a lesser degree, for the Anabolia genus. Oecetis ochracea and $L$. tineiformis showed the strongest affinity for lower EC values, while Phryganea grandis and Molanna angustata were associated with a bit higher values of EC. E. tenellus, Mystacides longicornis and Oecetis furva showed negative correlation with this factor.

CCA of the structural features of the reservoirs distinguished two crucial variables for caddisflies (Fig. 8): shading (conditional importance $\lambda a=0.33, F=1.80, p=0.008$ ) and the extent of development of elodeids (conditional importance $\lambda a=0.34, F=1.78, p=0.048$ ). Structural variables explained $21 \%$ of the total variance in the Trichoptera of the reservoirs. The first axis was defined by the extent of development of elodeids $(r=0.52)$ and the second by shading $(r=-0.67)$. Limnephilus decipiens, and to a lesser degree A. aterrimus, were the most closely associated with heavily shaded sites. In turn, $M$. longicornis and L. tineiformis were positively linked with more open sites. C. flavidus and $O$. furva were the species showing the strongest affinity for elodeids.

CCA for the landscape variables in buffer zones showed that six variables explained only $9.5 \%$ of the total variance in 


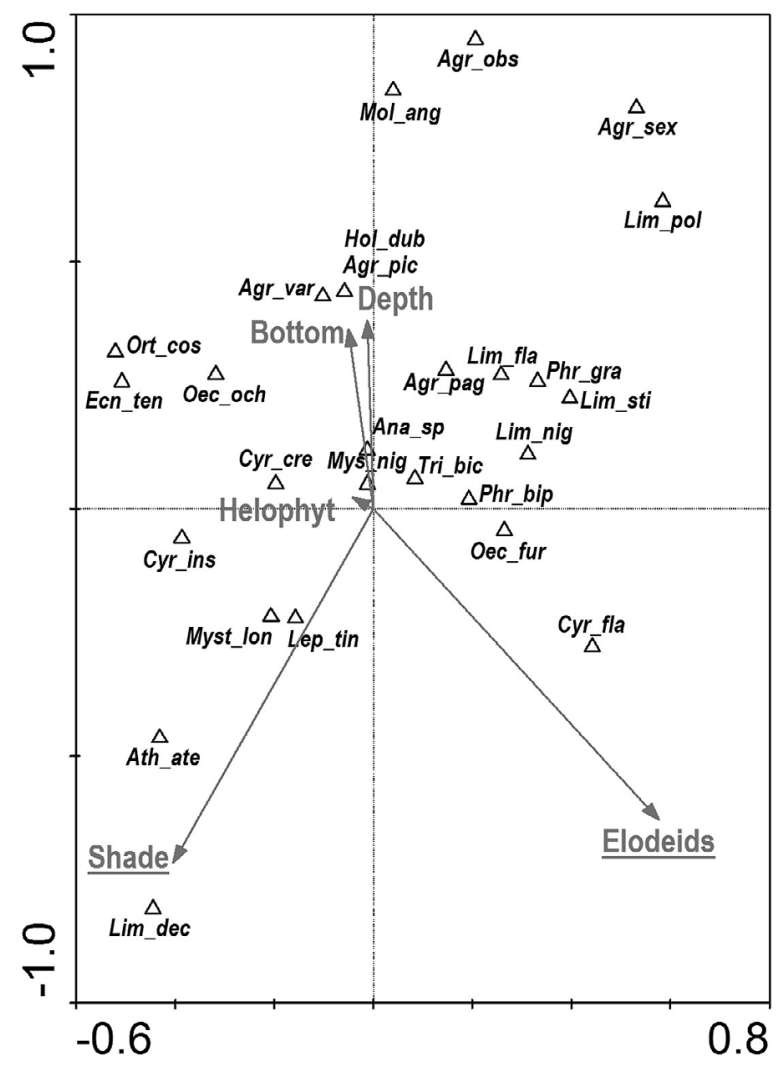

Fig. 8. CCA biplot showing the distribution of trichopteran taxa in storage reservoirs versus their structural features (Depth - water depth, Bottom - bottom type, Elodeids - extent of development of elodeids, Heloph - extent of development of helophytes, Shade level of shading). Statistically significant parameters are underlined. The taxon codes are explained in Table 2 .

the Trichoptera of the reservoirs (Fig. 9). Of these parameters, only the distance to the nearest standing water body (conditional importance $\lambda a=0.5, F=2.53, p=0.002$ ) was significant. The first ordination axis was defined by the only significant parameter $(r=0.84)$, and the second by the distance to the nearest running water $(r=0.73)$. T. bicolor was the most closely associated with the significant parameter. The large group of species situated below the arrow - mainly Phryganeidae and Limnephilidae - showed a clear affinity to this distance.

\section{Discussion}

\subsection{The general characteristic of the caddisfly fauna of the storage reservoirs}

The caddisfly fauna of river/canal-fed storage reservoirs is usually poor in species owing to anthropogenic disturbances; it resembles the fauna of mesotrophic lakes and contains a significant proportion of rheophilic species (Czachorowski, 1998). Even though the general species richness of the reservoirs studied is relatively low, the absence of rheophiles is atypical despite the origin of the water and the proximity of watercourses. Interestingly, such species were occasionally recorded in the lakes in the region, e.g. Hydropsyche angustipennis (Curtis, 1834) in Lake Piaseczno (Czachorowski and Kornijów, 1993) and Limnephilus rhombicus (Linnaeus, 1758) in Lake Skomielno (Buczyńska, 2012a). A study of the dragonflies of storage reservoirs in this region also revealed the absence of rheophilic species (Buczyński, 2015). This may be a regional feature of these reservoirs, and in a broader context, of the lakes as well, which in this lake district are very often linked by a network of ditches and canals (Michalczyk and Wilgat, 1998). According to the studies of Czachorowski (1998) and Czachorowski and Buczyński (1999b), the trichopterans fauna of these lakes is quite distinct from the fauna found in other Polish lake districts. This was attributed to the different origin of lakes (thermokarst processes in a chalk substrate), the influence of the close surroundings (fens) and predominantly sandy (soft) bottoms. For instance, the Agrypnia genus Curtis, 1835 was regarded as typical of the lakes in this part of Poland (Czachorowski, 1998). Similarly, the results of the present work show that Agrypnia species play a significant part in the dominance structure and the trichopteran assemblages Agrypnia varia and $A$. pagetana are key species of emergent vegetation assemblage A4. This genus, typical of ponds, marshes and lakes (Wiggins, 1998), can colonise various types of water bodies and move freely within the hydrological network of this lake district. The colonisation potential of this genus associated with the nearby pools and small fens was also confirmed by the results of CCA: A. pagetana was related to the closest distance to small pools in contrast to $A$. varia, A. obsoleta and A. picta.

\subsection{Reservoirs versus lakes - similarities and differences in the trichopteran fauna}

The assemblages of trichopteran larvae found in the reservoirs studied and the general species composition show that shallow storage reservoirs situated $28-37 \mathrm{~km}$ from the centre of the lake district may provide a suitable surrogate habitat for fauna from lakes with a given level of productivity. $\mathrm{R} 2$ is the reservoir most nearly lacustrine in character, as indicated by its naturalness indices: its fauna is qualitatively poorest but at the same time the most typical of a lacustrine environment. R1 is the least lacustrine, whereby its qualitative index is higher than that of meso/eutrophic and dystrophic lakes. The Wni index calculated for the entire fauna of the three reservoirs is not much lower than that calculated for the total fauna of the four lakes, whereas Wns is even higher in the reservoirs than in the lakes. What is more, the combined PIE indices for both habitat types are also very similar, whereas the evenness index is more than twice as high for the reservoirs than for the lakes (Tab. 3), which shows that the species are more evenly distributed in artificial waters. This confirms that the reservoirs have a very high lacustrine potential, and that their fauna contains even fewer incidental (atypical) species than in lakes, which may to some extent be due to their isolation.

The assemblages distinguished by TWINSPAN in this study correspond to those found in meso- and eutrophic lakes (Czachorowski, 1998); however, a more rigorous distinction between the assemblages of meso- and eutrophic lakes is difficult, which was confirmed by studies of the invertebrate assemblages in the eulittoral of 36 lakes in 


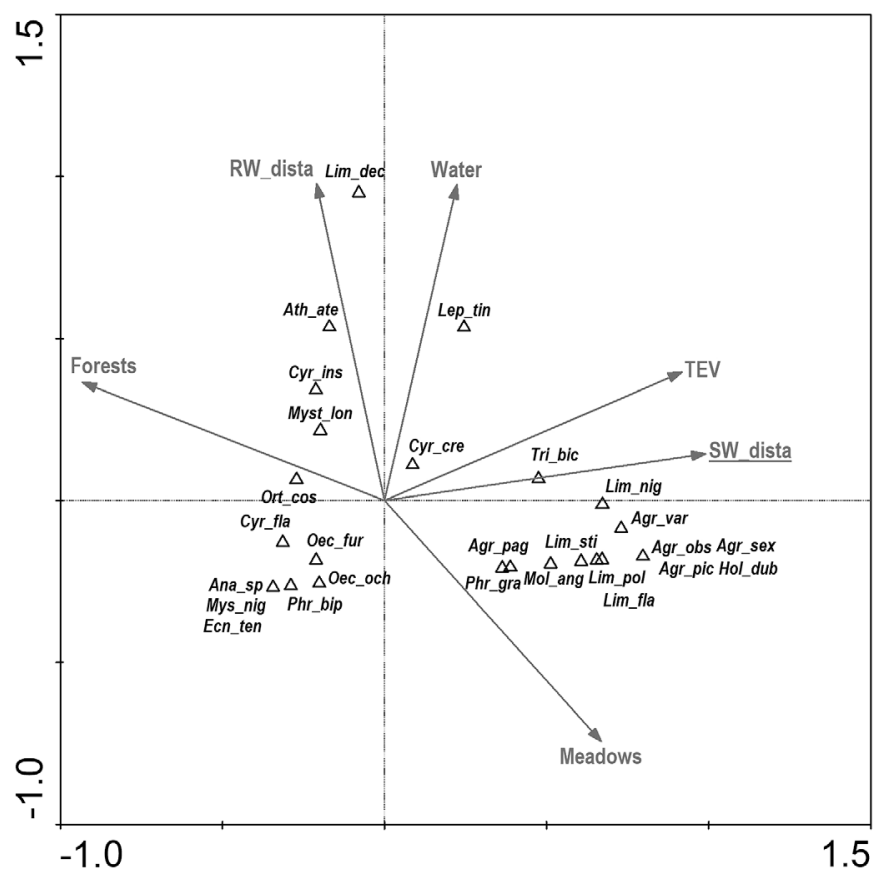

Fig. 9. CCA biplot showing the distribution of trichopteran taxa in storage reservoirs versus landscape metrics in buffer zones (Meadows - areas of wet meadows and fens, Forest - forests, Water - water, TEW - tall emergent vegetation, SW_dista - distance to the nearest standing water body, RW_dista - distance to the nearest running water. The statistically significant parameter is underlined. The taxon codes are explained in Table 2.

Germany (Brauns et al., 2007). The results of NMDS analysis also pointed to a fixed gradient scheme with respect to productivity. In general, the trichopteran assemblages found here are clearly linked with the vegetation zones in the lakes: A1 and A2 are typical of elodeids, where two families Polycentropodidae and Leptoceridae - are dominant; A4 is typical of emergent vegetation - here Limnephilidae and Phryganeidae are dominant; and A3 consists of species from various families preferring an unshaded sandy bottom. Only the predator-shredders Phryganeidae are found in every zone of these shallow reservoirs - this may be due to the various foraging strategies at different stages of their development: according to Wiggins (1998), early instars feed on plant fragments, late instars on aquatic insects, crustaceans and worms.

At the same time, the caddisfly fauna of each of the three reservoirs is of a slightly different character, which is the resultant of numerous biotic and abiotic factors. The lack of a uniform seasonal variability pattern provides further evidence for this. Emergent vegetation species - mainly the large detritivorous-predacious Limnephilidae - are best represented in $\mathrm{R} 1$, even though tall emergent vegetation is very well developed in all three reservoirs and in R2 occupies as much as $30 \%$ of the whole water surface. Perhaps, in the case of R2, the density of macrophytes is excessive: according to Tolonen et al. (2003), this acts to the detriment of trichopteran larvae. On the other hand, Cyrnus larvae are most numerous in R3 and R2: among them is C. flavidus, which was found to be the species most closely associated with well-developed elodeids and an indicator species for this vegetation zone. It might be interesting to compare the numerical ratio of $C$. crenaticornis to $C$. flavidus in the context of productivity. According to Czachorowski (1998), C. crenaticornis dominates C. flavidus in mesotrophic lakes, while the opposite situation prevails in eutrophic lakes. Alongside that line, R3 would be of a eutrophic nature, but R2 would be mesotrophic, which does not entirely correspond with the NMDS scheme. Again, Brinkmann et al. (1998), who studied the littoral fauna of 61 lakes in Germany, found $C$. crenaticornis to be typical of mesotrophic waters, whereas $C$. flavidus occurs in all trophic types. This would be closer to the results obtained in the present survey. In R3-and only in this reservoir - E. tenellus, a predator that spins webs to trap its preys, is a serious competitor for Cyrnus species, although this competition is somewhat reduced by their spatial separation: E. tenellus is never found at depths greater than $0.5 \mathrm{~m}$, whereas some Cyrnus larvae colonise the deeper waters of this reservoir, which contradicts literature data claiming that both genera are often found at large depths (Solem, 1973; Wallace, 1991). Interestingly, E. tenellus is regarded rather as a species typical of eutrophic lakes (Brinkmann et al. 1998; Czachorowski, 1998; O'Connor, 2015), whereas in the Łęczna-Włodawa Lake District it is found in the largest numbers in mesotrophic lakes and the faunistically equivalent reservoir R3.

\subsection{Three-level spatial factors influencing the distribution of caddisfly species in storage reservoirs}

The results of the CCAs show that caddisflies are dependent on factors acting both within a water body and in its close surroundings. The most important were the physical and chemical parameters of the water, followed by structural factors; the least important were factors associated with buffer zones. A number of authors (Galbraith et al., 2008; Skuja and Spungis, 2010; Savić et al., 2013; Buczyńska et al., 2017) consider the parameters of water to be of greater significance than the water body's structure and/or its surroundings/ catchment area as regard the distribution of caddisfly larvae in natural waters. Even though the percentage of explained variance in each category of factors obtained by those authors and in the present work is not always high (9-40\%), it is clear that these insects - as expected from their mode of life - are affected by factors acting at different spatial levels. Maintaining a suitable habitat for amphibiotic animals in artificial water bodies cannot therefore be limited to monitoring and management activities relating solely to the aquatic environment. Votruba and Broža (1989) emphasise that the conditions and water quality of reservoirs are favourable if the catchment area, soil management and agricultural activities are properly regulated.

ORP, EC and temperature are the most important physical and chemical parameters of water governing caddisfly assemblages. EC and temperature have been found most important to the development of caddisfly larvae in different types of waters (e.g. Kalaninová et al., 2014), including manmade reservoirs (Prommi and Thani, 2015; Buczyńska et al., 2016). ORP, on the other hand, is rarely mentioned in the literature. This is a factor strictly correlated with $\mathrm{DO}$ and $\mathrm{pH}$ : these two parameters will determine whether oxidation or 
reduction prevails in the water. ORP is also related to the amount of organic matter in the water and can be treated as a potential measure of BOD. It ranged from -46.5 to $+97 \mathrm{mV}$ in the storage reservoirs surveyed. According to Gerla (2013), this parameter can be especially important in calcareous wetlands characterised by a carbonate-rich substrate. Cai et al. (2011) found this factor to be crucial for benthic macroinvertebrate communities in a large shallow lake in China. They also demonstrated a connection between low ORP values and the decomposition of algae, which reduces the oxygen content, a key factor for particular invertebrate species. In alkaline waters, however, lower ORP is often accompanied by high oxygen content and does not necessarily imply less oxygen available to invertebrates. In reservoirs R1-R3, the oxygen contents varied during the year from 6.2 to 9.82 ; only in November do these values drop in R1 and R2 to just above 4 . This is why the oxygen content did not restrict the occurrence of caddisfly larvae, even potential rheophilic species, which have more strict demands regarding this parameter.

Plants are the most important structural variables affecting caddisfly assemblages - both aquatic (submerged and emergent) and terrestrial (trees and shrubs on the shore). Whereas a general definition of macrophytes will suffice in the case of most invertebrates displaying any association with aquatic vegetation whatsoever, in the case of Trichoptera, one is justified in distinguishing two vegetation zones - elodeids and helophytes - since each is inhabited/preferred by various species/assemblages with different foraging strategies. TWINSPAN revealed this very clearly. In CCA, elodeids were the key factors regarding the occurrence of caddisflies in storage reservoirs, as was the shade afforded by the woody vegetation on the shore. For a comparison, the extent of development of helophytes and the shade they provided were significant for the distribution of trichopteran larvae in a shallow dammed reservoir (Buczyńska et al., 2016). In addition, the extent of development of macrophyte cover in the water bodies of a small lowland river was one of the most important structural factors for larval caddisflies (Buczyńska et al., 2017). Weatherhead and James (2001) found positive relationships between Trichoptera and macrophyte biomass in the littoral zone of nine New Zealand lakes, and Tolonen et al. (2003) discovered that Trichoptera in three lakes in Finland were significantly affected by macrophytes. In general, macrophytes in shallow lakes support more ecological niches, which in turn allows more species to coexist (Hu et al., 2016). The elodeid zone of lakes is more stable, with fewer incidental species and a large number of limnobionts in comparison with the helophyte zone (Czachorowski, 1998). The species associated with elodeids in reservoirs R1-R3 exhibit a greater variety of foraging strategies than those from the helophyte zone. Perhaps this is favoured by the more diverse structure of shoots and leaves of the plants serving as a food resource, an anchorage for webs and larval cases, and the occurrence of a larger number of potential preys. Again, CCA revealed that the presence or absence of woody vegetation on the reservoir shores governs the occurrence of two quite different groups of species: the inflow of detritus to the reservoir used as a nutritional base (fine detritus) or as a substrate (coarser fraction) on which to attach the larval case is important to species positively correlated with shading - mainly leptocerid shredders. In contrast, negatively correlated species are more mobile, and may be carnivorous.

\subsection{Functional groups of caddisflies of the storage reservoirs}

Functional-feeding group (FFG) analysis, originally developed for running waters, has been successfully applied in standing waters. The occurrence and ratios of the particular groups help to identify the nutritional resource base for the water body, the availability of invertebrates to higher trophic levels, the habitat's physical stability for invertebrates, the capacity of invertebrates to colonise new habitats and changes/ disturbances within the water body (Merritt et al., 2002; Gerino et al., 2003). This study shows that the quantitative FFG structure in each reservoir is dominated by a different group, but the qualitative FFG structure is very similar and evenly balanced in all three reservoirs. The latter may confirm the fact that caddisflies have colonised most of the available trophic niches in each reservoir and that a certain stable system has evolved, which is a reflection of microhabitat heterogeneity. Large food resources are available in each reservoir for larvae of particular groups, regardless of microhabitat differences. A large proportion of predators (quantitative structure) in the youngest reservoir (R3) is characteristic - this arrangement could be evidence for the fact that, in contrast to the two older reservoirs, it has reached a crucial phase in its colonisation, when there is a shift from predators toward grazers and detritivores (Ruhí et al., 2009). One cannot state definitively whether this phenomenon is incidental or indeed associated with successional processes: at the time of sampling this reservoir was 11 years old; stable assemblage structuring patterns in artificial water bodies take varying lengths of time to develop - from 2-3 years (Voshell and Simmons, 1984) to 10 years (Ruhí et al., 2011). Nonetheless, the colonisation by Trichoptera of potential new habitats and the formation of assemblages is quite rapid. As the findings from this work have shown (CCAs), the process of colonisation requires the presence of small water bodies in the neighbourhood that supply an important pool of species. An identical relationship was found among the caddisflies of standing waters in the valley of a small lowland river (Buczyńska et al., 2017). This is because many lacustrine littoral species also colonise small bodies of standing water (Wallace, 1991) and migrate freely among them. Given the age of the three reservoirs, no dependence was found between this factor and the diversity metric or species richness: the oldest one had the lowest PIE index, whereas the other two, younger ones, had the highest taxonomic richness, and these values were higher than those calculated for three out of the four lakes used for a comparison. Similar results relating to taxonomic richness of macroinvertebrates from man-made ponds in Spain were obtained by Miguel-Chinchilla et al. (2014), who concluded that local environment characteristics and complexity are of greater validity than the age of the pond.

\subsection{Storage reservoirs - importance for aquatic fauna and practical issues for sustainable management}

Accelerating silting up and overgrowing of the lakes in the Łęczna-Włodawa Lake District (Michalczyk and Wilgat, 1998), one can perhaps state that storage reservoirs may in the future become important refuges of species and 
assemblages typical of meso- and eutrophic lakes. At present, storage reservoirs can provide suitable secondary habitats for caddisflies and are expanding the range of lacustrine species beyond the lake district itself, forming a specific, valuable genetic and colonisation pool of these insects. The same conclusions were provided for odonates of storage reservoirs of this region (Buczyński, 2015). The level of human pressure in these reservoirs is much lower than in typical, deep dammed reservoirs: variations in water level are fewer, water retention is slower and destruction of the shoreline and littoral zone - including vegetation - even if it does occur, is ephemeral and local. Removal of some vegetation, for example for the benefit of anglers or other recreational purposes, and the planting of trees along the shores can be treated as actions advantageous to the fauna. As a result, storage reservoirs can supply a range of habitat niches for both vertebrates and invertebrates, which can enhance regional biodiversity. By managing the vegetation, one can maintain the reservoirs (or parts of them) in various stages of succession: the effects of this have been positive in the case of fish ponds (Buczyńska et al., 2007) and peat pools (Wildermuth, 2001). The present work, like the survey of the macrofauna of three shallow lakes in China (Hu et al., 2016), has shown that particular assemblages are associated with a specific level of productivity in a water body. This knowledge can be used to detect rising levels of eutrophication, one of the more serious problems affecting standing waters, which are also detrimental to biotic communities (Strayer and Dudgeon, 2010). Defining FFG compositions and proportions can help in assessing the availability of nutritional resources in a water body. Walker et al. (2013) found that a healthy, macrophyte-dominated, ecological state is needed for maintaining the biodiversity and conservation value of ponds. One can add here that the presence of certain groups of caddisflies may be useful in assessing whether the proportion of elodeids to helophytes is evenly balanced and thus beneficial to the ecosystem or not in the latter case, some management of macrophyte growth would be desirable.

\section{References}

Biesiadka E. 1980. Water beetles (Coleoptera) of the eutrophic lake Zbęchy (Leszno voiv.). Pol Ecol Stud 6: 263-275.

Brauns M, Garcia XF, Pusch MT, Walz N. 2007. Eulittoral macroinvertebrate communities of lowland lakes: discrimination among trophic states. Freshw Biol 52: 1022-1032.

Brinkmann R, Lettow G, Schwahn J, Speth S. 1998. Untersuchungen zur Litoralfauna schleswig-holsteinischer Seen: Veranlassung, Zielsetzung - Teil I: Köcherfliegen (Trichoptera). Lauterbornia 34: 31-44.

Buczyńska E. 2012a. Caddisflies (Trichoptera). In: Kornijów R, Buczyński P, eds. Lake Skomielno (Łęczna-Włodawa Lakeland, Eastern Poland). Environment monograph. Olsztyn: MANTIS, pp. 273-288.

Buczyńska E. 2012b. Caddisflies (Trichoptera) of the Poleski National Park - state of knowledge, threats and perspectives. In: Dyguś KH, ed. Natural human environment: dangers, protection, education. Warszawa: Oficyna Wydawnicza Wyższej Szkoły Ekologii i Zarządzania, pp. 135-159.

Buczyńska E, Buczyński P, Lechowski L, Stryjecki R. 2007. Fish pond complexes as refugia of aquatic invertebrates (Odonata, Coleoptera, Heteroptera, Hydrachnidia): a case study of the pond complex in Zalesie Kańskie (central-east Poland). Nat Conserv 64: 39-55.

Buczyńska E, Buczyński P, Zawal A, Stępień E. 2016. Environmental factors affecting microdistribution of larval caddisflies (Trichoptera) in a small lowland reservoir under different watershed usage. Fundam Appl Limnol 188: 157-170.

Buczyńska E, Czachorowski S, Buczyński P, Pakulnicka J, Stępień E, Szlauer- Łukaszewska A, Stryjecki R, Zawal A. 2017. Environmental heterogeneity at different scales: key factors affecting caddisfly larvae assemblages in standing waters within a lowland river catchment. J Limnol 76: 305-325.

Buczyński P. 2015. Dragonflies (Odonata) of Anthropogenic Waters in Middle-Eastern Poland. Olsztyn: MANTIS, $272 \mathrm{pp}$.

Buzas MA, Gibson TG. 1969. Species diversity: benthonic foraminifera in western North Atlantic. Science 163: 72-75.

Cai Y, Gong Z, Qin B. 2011. Influences of habitat type and environmental variables on benthic macroinvertebrate communities in a large shallow subtropical lake (Lake Taihu, China). Ann Limnol 47: 85-95.

Céréghino R, Biggs J, Oertli B, Declerck S. 2008. The ecology of European ponds: defining the characteristics of a neglected freshwater habitat. Hydrobiologia 597: 1-6.

Chapman D. (ed.). 1996. Water Quality Assessments: A Guide to the Use of Biota, Sediments and Water in Environmental Monitoring, 2nd ed. London: E\&FN Spon, 651 pp.

Czachorowski S. 1998. Caddisflies (Trichoptera) of Polish Lakes Characteristics of Distribution of Larvae. Olsztyn: Wydawnictwo WSP w Olsztynie, 156 pp. (in Polish).

Czachorowski S. 2004. Biocenosis naturality indexes as a tool in planning nature protection and biocenosis monitoring. Trichopteron 11: 8-12 (in Polish).

Czachorowski S, Buczyński P. 1999a. Biocenosis naturality index - a prospective instrument in an evaluation of the ecological state of Polish fens and peatbogs, on example of Odonata and Trichoptera. In: Radwan S, Kornijów R, eds. Problems of protection of aquatic, fen and peat bog ecosystems in Polish national parks. Lublin: Wydawnictwo UMCS, pp. 153-158 (in Polish).

Czachorowski S, Buczyński P. 1999b. Remarks on caddisflies (Insecta: Trichoptera) of the Poleski National Park and its environs. Parki Nar Rez Przyr 18: 103-110 (in Polish).

Czachorowski S, Kornijów R. 1993. Analysis of the distribution of caddis larvae (Trichoptera) in the elodeid zone of two lakes of East Poland, based on the concept of habitatual islands. Pol Arch Hydrobiol 40: 165-180.

Čiliak M, Novikmec M, Svitok M. 2014. Biological zonation of the last unbound big river in the West Carpathians: reference scheme based on caddisfly communities. Knowl Manag Aquat Ecosyst 415: 4.

de Moor FC, Ivanov VD. 2008. Global diversity of caddisflies (Trichoptera: Insecta) in freshwater. Hydrobiologia 595: 393-407.

Edington JM, Hildrew AG. 1995. A revised key to the caseless caddis larvae of the British Isles with notes on their ecology, Freshwater Biological Association Scientific Publication, 53. Ambleside, Cumbria: Freshwater Biological Association, $134 \mathrm{pp}$.

Fadilah U, Atmowidi T, Priawandiputra W. 2017. Comparison of aquatic insect assemblages between managed and unmanaged artificial lakes in Indonesia. J Entomol Zool Stud 5: 496-506.

Fischer J. 1996. Bewertungsverfahren zur Quellfauna. Crunoecia 5: $227-240$

Galbraith HS, Vaughn CC, Meier CK. 2008. Environmental variables interact across spatial scales to structure trichopteran assemblages in Ouachita Mountain Rivers. Hydrobiologia 596: $401-411$. 
Gerino M, Stora G, François-Carcaillet F, Gilbert F, Poggial J-C, Mermillod-Blondin F, Desrosiers G, Vervier P. 2003. Macroinvertebrate functional groups in freshwater and marine sediments: a common mechanistic classification. Vie Milieu 53: 221-231.

Gerla PJ. 2013. Can $\mathrm{pH}$ and electrical conductivity monitoring reveal spatial and temporal patterns in wetland geochemical processes? Hydrol Earth Syst Sci Discuss 10: 699-728.

Graf W, Murphy J, Dahl J, Zamora-Muñoz C, López-Rodríguez MJ. 2008. Distribution and Ecological Preferences of European Freshwater Organisms, Vol. 1: Trichoptera. Moscow-Sofia: Pensoft, 388 pp.

Hammer R, Harper DAT, Ryan PD. 2001. PAST: paleontological statistics software package for education and data analysis. Palaeontol Electronica 4: 1-9.

Hill MO, Šmilauer P. 2005. TWINSPAN for Windows version 2.3. České Budějovice: Centre for Ecology and Hydrology and University of South Bohemia.

Hu Z, Sun X, Cai Y, Guo L, Chen Q, Liu T, Shi F, Yang L. 2016. The habitat type and trophic state determine benthic macroinvertebrate communities in lowland shallow lakes of China. J Limnol 75: 330-339.

Kalaninová D, Bulánková E, Šporka F. 2014. Caddisflies (Trichoptera) as good indicators of environmental stress in mountain lotic ecosystems. Biologia 69: 1030-1045.

Kondracki J. 2014. Regional Geography of Poland, Warszawa: Wydawnictwo Naukowe PWN, 441 pp. (in Polish).

Lampert W, Sommer U. 1999. Limnoökologie. Stuttgart: Thieme, $489 \mathrm{pp}$.

Lepš J, Šmilauer P. 2003. Multivariate Analysis of Ecological Data Using CANOCO. Cambridge: Cambridge University Press, 269 pp.

Malm T, Johanson KA, Wahlberg N. 2013. The evolutionary history of Trichoptera (Insecta): a case of successful adaptation to life in freshwater. Syst Entomol 38: 459-473.

Merritt RW, Cummins KW, Berg MB, Novak JA, Higgins MJ, Wessell KJ, Lessard JL. 2002. Development and application of a macroinvertebrate functional-group approach in the bioassessment of remnant river oxbows in southwest Florida. J North Am Benthol Soc 21: 290-310.

Michalczyk Z, Wilgat T. 1998. Water Relations of the Lublin Region. Lublin: Wydawnictwo UMCS, 167 pp. (in Polish).

Miguel-Chinchilla L, Boix D, Gascón S, Comín FA. 2014. Macroinvertebrate biodiversity patterns during primary succession in manmade ponds in north-eastern Spain. J Limnol 73: 428-440.

O'Connor JP. 2015. A catalogue and atlas of the caddisflies (Trichoptera) of Ireland. Occas Publ Irish Biogeogr Soc 11: 1-646.

O'Hara RB, Kotze DJ. 2010. Do not log-transform count data. Methods Ecol Evol 1: 118-122.

Poznańska M, Kobak J, Wolnomiejski N, Kakareko T. 2009. Shallowwater benthic macroinvertebrate community of the limnic part of a lowland Polish dam reservoir. Limnologica 39: 163-176.

Prommi TO, Thani I. 2015. Diversity of trichoptera fauna and its correlation with water quality parameters at Pasak Cholasit reservoir, Central Thailand. Environ Nat Res $J$ 12: 35-41.

Prus T, Prus M, Bijok P. 1999. Diversity of invertebrate fauna in littoral of shallow Myczkowce dam reservoir in comparison with a deep Solina dam reservoir. In: Walz N, Nixdorf B, eds. Shallow Lakes '98: Trophic Interactions in Shallow Freshwater and Brackish Waterbodies. Dordrecht: Springer Science+Business Media, B.V., pp. 203-210.
QGIS Development Team. 2015. QGIS Geographic Information System, Open Source Geospatial Foundation Project. Available at http://qgis.osgeo.org (accessed 7 February 2017).

Ruhí A, Boix D, Sala J, Gascón S, Quintana XD. 2009. Spatial and temporal patterns of pioneer macrofauna in recently created ponds: taxonomic and functional approaches. Hydrobiologia 634: 137-151.

Ruhí A, Herrmann J, Gascón S, Sala J, Geijer J, Boix D. 2011. Change in biological traits and community structure of macroinvertebrates through primary succession in a man-made Swedish wetland. Freshw Sci 31: 22-37.

Samways MJ, Osborn R, van Heerden Koedoe I. 1996. Distribution of benthic invertebrates at different depths in a shallow reservoir in the KwaZulu-Natal Midlands. Koedoe 39: 69-76.

Savić A, Ranđelović V, Đorđević M, Karadžić B, Đokić M, KrpoĆetković J. 2013. The influence of environmental factors on the structure of caddisfly (Trichoptera) assemblage in the Nišava River (Central Balkan Peninsula). Knowl Manag Aquat Ecosyst 409: 1-18.

Skuja A, Spungis V. 2010. Influence of environmental factors on the distribution of caddisfly (Trichoptera) communities in mediumsized lowland stream in Latvia. Estonian J Ecol 59: 197-215.

Solem JO. 1973. The bottom fauna of Lake Lille-Jonsvann, Trondelag, Norway. Norway J Zool 21: 227-261.

Strayer DL, Dudgeon D. 2010. Freshwater biodiversity conservation: recent progress and future challenges. J North Am Benthol Soc 29: 344-358.

Szujecki A. 1983. Ecology of forest insects. Warszawa: Państwowe Wydawnictwo Naukowe, 604 pp. (in Polish).

ter Braak CJF, Smilauer P. 2002. CANOCO Reference Manual and CanoDraw for Windows User's Guide: Software for Canonical Community Ordination (Version 4.5). Ithaca, NY: Microcomputer Power, 500 pp.

Tolonen KT, Hämäläinen H, Holopainen IJ, Mikkonen K, Karjalainen J. 2003. Body size and substrate association of littoral insects in relation to vegetation structure. Hydrobiologia 499: 179-190.

Voshell JR, Simmons GM. 1984. Colonization and succession of benthic macroinvertebrates in a new reservoir. Hydrobiologia 112: $27-39$.

Votruba L, Broža V. 1989. Water Management in Reservoirs. New York: Elsevier Science, 441 pp.

Walker PD, Wijnhoven S, van der Velde G. 2013. Macrophyte presence and growth form influence macroinvertebrate community structure. Aquat Bot 104: 80-87.

Wallace ID. 1991. Research and Survey in Nature Conservation No. 32: A Review of the Trichoptera of Great Britain, Peterborough: Nature Conservancy Council, Northminster House, $55 \mathrm{pp}$.

Wallace ID, Wallace B, Philipson GN. 2003. Freshwater Biological Association Scientific Publication 61: Keys to the Case-Bearing Caddis Larvae of Britain and Ireland. Ambleside, Cumbria: Freshwater Biological Association, 259 pp.

Weatherhead MA, James MR. 2001. Distribution of macroinvertebrates in relation to physical and biological variables in the littoral zone of nine New Zealand lakes. Hydrobiologia 462: 115-129.

Wiggins GB. 1998. The Caddisfly Family Phryganeidae (Trichoptera). Toronto: University of Toronto Press, $248 \mathrm{pp}$.

Wildermuth H. 2001. Das Rotationsmodell zur Pflege kleiner Moorgewässer - Simulation naturgemäßer Dynamik. Natschutz Landschaftspl 33: 269-273. 